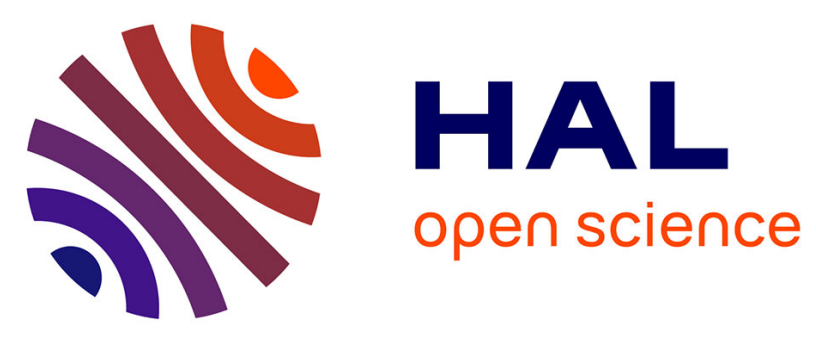

\title{
What Do We Think About Muslims? The Validity of Westerners' Implicit Theories About the Associations Between Muslims' Religiosity, Religious Identity, Aggression Potential, and Attitudes Toward Terrorism
}

Peter Fischer, Tobias Greitemeyer, Andreas Kastenmüller

\section{To cite this version:}

Peter Fischer, Tobias Greitemeyer, Andreas Kastenmüller. What Do We Think About Muslims? The Validity of Westerners' Implicit Theories About the Associations Between Muslims' Religiosity, Religious Identity, Aggression Potential, and Attitudes Toward Terrorism. Group Processes and Intergroup Relations, 2007, 10 (3), pp.373-382. 10.1177/1368430207078697 . hal-00571657

\section{HAL Id: hal-00571657 \\ https://hal.science/hal-00571657}

Submitted on 1 Mar 2011

HAL is a multi-disciplinary open access archive for the deposit and dissemination of scientific research documents, whether they are published or not. The documents may come from teaching and research institutions in France or abroad, or from public or private research centers.
L'archive ouverte pluridisciplinaire HAL, est destinée au dépôt et à la diffusion de documents scientifiques de niveau recherche, publiés ou non, émanant des établissements d'enseignement et de recherche français ou étrangers, des laboratoires publics ou privés. 


\title{
What Do We Think About Muslims?
} The Validity of Westerners' Implicit Theories About the Associations Between Muslims' Religiosity, Religious Identity, Aggression Potential, and Attitudes Toward Terrorism

\author{
Peter Fischer \\ Ludwig-Maximilians-University, Munich \\ Tobias Greitemeyer \\ Ludwig-Maximilians-University, Munich \\ Andreas Kastenmüller \\ Ludwig-Maximilians-University, Munich
}

\begin{abstract}
In a series of three studies, we investigated the validity of implicit theories that the German public holds regarding Muslims. German participants expected Muslims to be more aggressive than Christians, and therefore be more supportive of terrorism than Christians. Furthermore, Muslims were assumed to be more intrinsically religious and to hold a stronger identity with their religion than Christians (Study 1). However, self-assessment surveys of Muslims and Christians in the Commonwealth of Independent States (CIS: ex-Soviet Union) revealed that Muslims were not more aggressive, more intrinsically religious, or more supportive of terrorism than Christians. In contrast, Muslims reported a stronger religious identification than Christians (Study 2). Correspondingly, threat to religious identity was found to affect only Muslims', but not Christians', attitudes toward terrorism conducted by outgroup perpetrators. In contrast to Germans' implicit theories regarding Muslims, it was the importance of religious identity and not increased aggression potential that mediated this effect (Study 3).
\end{abstract}

KEYWORDs aggression, Christians, Muslims, religious identification, terrorism

Over the past 5 years, prolific and devastating terrorist attacks conducted by Islamic fundamentalists in America (mostly notably the World Trade Center attack of September 11, 2001), the European Union (e.g. the train

\section{Author's note}

Address correspondence to Peter Fischer, Department of Psychology, Social Psychology Unit, Ludwig-Maximilians-University, Leopoldstrasse 13, 80802 Munich, Germany [e-mail: pfischer@psy.uni-muenchen.de] 
bombing in Madrid on March 11, 2004; the London underground attack in July, 2005), Asia (e.g. the Bali bombings of October 12, 2002) and the Middle East (e.g. almost daily attacks and suicide bombings in Iraq and Israel) against Western interests and rival Islamic groups have dramatically changed the global political climate and are likely to have heavily impacted on the general perception that Westerners hold regarding Muslims. As a consequence of these frequent and recent terrorist attacks conducted by Islamic fundamentalists, in addition to other factors such as frequent media reports on terrorist attacks or political justifications of Western counterterrorist activity (e.g. 'War on terror' in Afghanistan and Iraq; 'Operation Enduring Freedom'), specific implicit theories and stereotypes of 'how Muslims really are' relative to Christians may have emerged within western Christian societies. First of all, Muslims might be expected to be more intrinsically religious than Christians because many fundamentalists have died (and are willing to sacrifice themselves) as suicide bombers in the name of their religion. Second, religious identity might be more important to Muslims than Christians, because many Muslim nations do not distinguish between church and state and thus try to prevent secularization. Third, because of frequent suicide bombings in Israel and Iraq, the broadcast executions of Americans and hostages of other nationalities in Iraq, and public proclamations by Muslim terrorist leaders (e.g. Osama Bin Laden) to fight the enemies of 'the true faith', Christians might expect Muslims to be extraordinarily aggressive. Fourth, and finally, because most of the recent spate of terrorist attacks were conducted by Islamic extremists, and due to other powerful media images such as those showing Muslims celebrating the attacks on the World Trade Center, Muslims might be expected to be more supportive of terrorism as a justified political instrument than Christians. ${ }^{1}$

Why is it important to know more about Westerners' implicit theories of Muslims? Implicit theories are construction frameworks that people use in everyday life to interpret and evaluate their social world (Dweck, Chiu, \& Hong, 1995; Hong, Levy, \& Chiu, 2001), guide social judgments, and develop social actions (Levy, 1999; Levy, Plaks, Hong, Chiu, \& Dweck, 2001). If members of Western Christian societies really subscribe to the above-mentioned implicit theories on Muslims, it could have far ranging and serious consequences for the understanding of and social interaction with the Islamic world. An assumption by Christians that Muslims are extraordinarily aggressive or inclined towards terrorism could be expected to lead to a different attitude toward Muslims than an assumption that they are placid people who generally condemn terrorism.

Because religiously motivated terrorism is one of the biggest social challenges facing modern Western societies at the present time, in this study we primarily focused on expected and actual attitudes of Muslims and Christians toward terrorism, as well as the underlying psychological mechanisms propelling these perceptions and attitudes. We report on three studies that investigated: Germans' implicit theories on Muslims and Christians (Study 1); tested their validity with self-assessment surveys of Muslims and Christians in the Commonwealth of Independent States (CIS: ex-Soviet Union) (Study 2); and finally pointed out the specific role of religious identity in attitudes toward terrorism as a political instrument (Study 3).

\section{Study 1}

Germans in Munich, Bavaria-a predominantly Catholic and arguably the most conservative of German states-were asked about their perceptions of Christians and Muslims living in the CIS (which contains countries like Azerbaijan, whose population is $95 \%$ Muslim and which is located near Iran) in terms of their religiousness, importance of religious identity, aggression potential, and attitudes toward terrorism. Compared to Christians, we assumed that Germans expected Muslims to be: (a) more intrinsically religious; (b) more strongly religiously identified; (c) more aggressive; and (d) more accepting of terrorism. We expected these perceptions to be independent of whether German participants were of a Christian denomination or not. If our assumption was 
correct, then the expected effects should not be likely due to processes of social identity related to religious affiliation (Tajfel, 1982). In other words, expected effects should not be mainly based on German Christians stereotyping of Muslims because they consider the latter to be a religious outgroup.

\section{Method}

Participants and design In total, 119 passers-by at a pedestrian zone ( 67 females and 52 males, ages ranging from 15 to 66 years; $M=32.49$, $S D=14.17)$ participated in Study 1, which was based on a 2 (religion of target group: Christian vs. Muslim) $\times 2$ (denomination of participants: Christian vs. no denomination) factorial betweensubject design.

Material and procedure Participants were recruited at a pedestrian zone near the LudwigsMaximilians-University Munich campus and asked whether they would be willing to participate in a study dealing with attitudes towards different religions. If they agreed, they were led to an experimental lab at the nearby University campus and read the following synopsis:

Religion is an important part of many societies and many peoples' daily life. Therefore, it is important to learn as much as possible about religion in different cultures. In the present study, we are interested in your perception of Muslims (Christians) in the CIS (ex-Soviet Union).

Subsequently, participants estimated Muslims' (Christians') aggression potential using a German translation of an aggression questionnaire by Buss and Perry (1992). This translation was modified from a first-person to a third-person perspective $(\alpha=.93)$. Next (and in keeping with single-item measurement of attitudes), participants were asked on a scale from 0 (not at all) to 10 (extremely) to what extent they supposed that Muslims (Christians) condone terrorism as a justified political instrument. Lastly, participants reported to what extent they assumed that religious identity is important to Muslims (Christians) $(0=$ not at all important $; 10=$ extremely important $)$. The distinction between religiosity and religious identity is useful, because religiosity concerns the degree of a person's religious participation whereas, by contrast, religious identity concerns the affiliation of a person with a certain religious group (see Regnerus, 2003, who also measured importance of religious identity using a single item). Finally, participants were asked to assess Muslims' (Christians') degree of intrinsic religiosity $(\alpha=.61)$ in a German translation (Zwingmann, Hellmeister, \& Ochsmann, 1994) of the religious orientation scale by Feagin (1964). Because intrinsic religiosity is the measure for 'real' and lived religiosity (Allport \& Ross, 1967; Bergin, 1991; Hill \& Pargament, 2003), we only used intrinsic religiosity as a measure of religiosity (as opposed to extrinsic religiosity). Finally, participants indicated in open-ended question format their own religious denomination, were informed about the actual aim of the investigation, and were dismissed.

\section{Results and Discussion}

A $2 \times 2 \times 4$ factorial multivariate analysis of variance (MANOVA) with 'religion of target group' (Muslims vs. Christians) and 'denomination of participants' (Christian vs. none) as betweenparticipant factors, and intrinsic religiosity, importance of religious identity, aggression potential and attitudes toward terrorism as dependent variables, revealed a significant main effect for 'religion of target group' (multivariate $\left.F(4,112)=9.25, p<.001, \eta^{2}=.25\right)$. All means and standard deviations are reported in Table 1. Univariate follow-up analyses revealed that Muslims (compared to Christians) were expected to be more intrinsically religious $(F(1$, $\left.115)=20.29, p<.001, \eta^{2}=.15\right)$, to have a greater religious identification $(F(1,115)=8.35, p<.01$, $\left.\eta^{2}=.07\right)$, to be more aggressive $(F(1,115)=5.69$, $\left.p=.02, \eta^{2}=.05\right)$, and to be more supportive of terrorism as a justified political instrument $\left(F(1,115)=15.66, p<.001, \eta^{2}=.12\right)$. No significant interaction was observed between 'religion of target group' and 'denomination of participants' (multivariate $F(4,112)=0.60$, $\left.p>.66, \eta^{2}=.02\right)$, indicating that the effects reported above were probably not mainly due to processes of social categorization by (or due to issues of social identity of) German Christians (compared to non-Christian German 
Table 1. Means and standard deviations of dependent variables as a function of target group (Study 1) or own religion (Study 2)

\begin{tabular}{|c|c|c|c|c|}
\hline & \multicolumn{2}{|c|}{$\begin{array}{c}\text { Study } 1 \\
\text { Implicit theories } \\
\text { (target group) }\end{array}$} & \multicolumn{2}{|c|}{$\begin{array}{c}\text { Study } 2 \\
\text { Real attitudes } \\
\text { (own religion) }\end{array}$} \\
\hline & Muslims & Christians & Muslims & Christians \\
\hline $\begin{array}{l}\text { Intrinsic } \\
\text { religiosity }^{\mathrm{b}}\end{array}$ & $\begin{array}{c}6.12 \\
(1.18)^{\mathrm{a}}\end{array}$ & $\begin{array}{c}4.65 \\
(1.47)\end{array}$ & $\begin{array}{c}5.03 \\
(1.97)\end{array}$ & $\begin{array}{c}4.92 \\
(2.40)\end{array}$ \\
\hline $\begin{array}{l}\text { Religious } \\
\text { identity }^{c}\end{array}$ & $\begin{array}{c}8.38 \\
(2.14)\end{array}$ & $\begin{array}{c}6.60 \\
(2.55)\end{array}$ & $\begin{array}{c}8.08 \\
(3.17)\end{array}$ & $\begin{array}{c}6.11 \\
(3.42)\end{array}$ \\
\hline $\begin{array}{l}\text { Aggression } \\
\text { potential }^{\mathrm{d}}\end{array}$ & $\begin{array}{c}2.70 \\
(0.73)\end{array}$ & $\begin{array}{c}2.23 \\
(0.63)\end{array}$ & $\begin{array}{c}2.62 \\
(0.53)\end{array}$ & $\begin{array}{c}2.67 \\
(0.51)\end{array}$ \\
\hline $\begin{array}{l}\text { Attitude } \\
\text { toward } \\
\text { terrorism }\end{array}$ & $\begin{array}{c}4.11 \\
(3.03)\end{array}$ & $\begin{array}{c}1.55 \\
(2.24)\end{array}$ & $\begin{array}{c}1.25 \\
(2.54)\end{array}$ & $\begin{array}{c}2.96 \\
(4.12)\end{array}$ \\
\hline
\end{tabular}

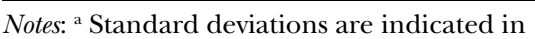
parentheses. ${ }^{\mathrm{b}}$ Scale ranges between 1 and 9 . ${ }^{\mathrm{c}}$ Scale ranges between 0 and $10 .{ }^{\mathrm{d}}$ Scale ranges between 1 and 5 . ${ }^{\mathrm{e}}$ Scale ranges between 0 and 10 .

participants) of a religious outgroup such as Muslims.

Mediational analysis A mediational analysis that followed Baron and Kenny's (1986) mediation criteria was conducted in order to investigate whether Muslims were expected to be more accepting of terrorism because they were assumed to be extraordinarily: (a) aggressive; (b) intrinsically religious; or (c) strongly identified with their religion. Preliminary regression analyses revealed that only the assumed aggression potential was a potential mediator for different expectations about Christians' and Muslims' attitudes toward terrorism. First of all, a regression analysis with the experimental condition 'religion of target group' as a predictor variable and the dependent variable 'attitudes toward terrorism' as a criterion variable revealed a significant regression weight $(\beta=-.44 ; t(117)$ $=-5.22, p<.001)$. Second, a regression analysis with 'religion of target group' as a predictor and the assumed mediator 'expected aggression potential' as a criterion variable also revealed a significant regression weight $(\beta=-.33 ; t(117)$ $=-3.81, p<.001)$. Third, a regression analysis with the assumed mediator 'expected aggression potential' as a predictor and the dependent variable 'attitudes toward terrorism' as a criterion variable revealed a significant regression weight $(\beta=.66 ; t(117)=9.44, p<.001)$. Finally, a regression analysis with the predictors 'religion of target group' and 'expected aggression potential' that simultaneously predicted the criterion 'attitudes toward terrorism' revealed a significant regression equation $\left(R^{2}=.49\right.$; $F(2,116)=54.55, p<.001)$. Both the expected aggression potential $(\beta=.58 ; t(117)=8.16$, $p<.001)$ and 'religion of target group' $(\beta=-.24$; $t(117)=-3.44, p<.01)$ reached a significant regression weight. A Sobel Test revealed that the indirect effect of the independent variable (religion of target group) on the dependent variable (attitudes toward terrorism) via the mediator (expected aggression potential) was significantly different from zero $(Z=-3.44$, $p<.001)$. Hence, the unmediated $\beta$-coefficient for religion of target group on attitudes toward terrorism significantly decreased when the expected aggression potential was controlled for. Thus, the expected aggression potential mediated the effect of religion of target group on attitudes toward terrorism.

In sum, Study 1 confirmed our expectations: German participants assumed Muslims to be more religious, more aggressive, more strongly identified with their religion, and more accepting of terrorism than Christians. Furthermore, a mediational analysis revealed that participants expected Muslims to be more accepting of terrorism because they were expected to be more aggressive than Christians. By contrast, intrinsic religiosity and importance of religious identity were not significant mediators. In the next step, we investigated whether Muslims are indeed more intrinsically religious, more strongly identified with their religion, more aggressive, and more supportive of terrorism than Christians by directly surveying Christians and Muslims via self-assessment.

\section{Study 2}

Muslims and Christians from the CIS were asked about their intrinsic religiosity, the importance of their religious identity, aggression potential, and their attitudes toward terrorism. 


\section{Method}

Participants and design Participants were recruited in two nations of the CIS (Ukraine and Azerbaijan). Fifty-one (27 females and 24 males, ages ranging from 17 to 84 years; $M=42.43, S D=15.12)$ Christians $(N=27$; age: $M=40.67, S D=14.76)$ and Muslims $(N=24$; age: $M=44.00, S D=15.80)$ participated in Study 2, which was based on a 2 (religion: Christian vs. Muslim) $\times 4$ factorial multivariate design with intrinsic religiosity, importance of religious identity, aggression, and attitudes toward terrorism as dependent variables.

Material and procedure Participants read instructions similar to those of Study 1. The only difference was that the present study focused on the participants' own attitudes, rather than on stereotypes and expectations of Muslims and Christians. After having read the introduction, participants indicated their religious denomination. Subsequently, participants answered a Russian translation of the same questions and scales used in Study 1; that is, a scale of intrinsic religiosity $(\alpha=.79$; Feagin, 1964), aggression potential $(\alpha=.83$; Buss \& Perry, 1992), importance of religious identity, and attitudes toward terrorism. Finally, participants were informed about the aim of the investigation, thanked for their participation, and dismissed.

\section{Results and discussion}

A $2 \times 4$ MANOVA with religion of participants (Muslims vs. Christians) as a betweenparticipants factor, and intrinsic religiosity, importance of religious identity, aggression, and attitudes toward terrorism as dependent variables, revealed a significant main effect for type of religion (multivariate $F(4,46)=2.64$, $\left.p<.05, \eta^{2}=.19\right)$. All means and standard deviations are reported in Table 1 . Univariate follow-up analyses revealed that religious identity was more important to Muslims than Christians $\left(F(1,49)=4.51, p<.05, \eta^{2}=.08\right)$. In contrast, no differences between religious groups were observed regarding intrinsic religiosity $\left(F(1,49)=0.04, p=.85, \eta^{2}=.00\right)$, aggression potential $(F(1,49)=0.12, p=.73$, $\left.\eta^{2}=.00\right)$, and attitudes toward terrorism $\left(F(1,49)=3.10, p=.09, \eta^{2}=.06\right)$.

Study 2 revealed that three of four implicit theories that Germans hold regarding Muslims (as compared to Christians) were without basis: Muslims did not report that they were more intrinsically religious, more aggressive, or more supportive of terrorism than Christians. However, Muslims reported that their religious identity is more important to them than did Christians. This result might have important implications for Muslims' and Christians' attitudes toward terrorism as a political instrument: if a terrorist attack is conducted by a Christian perpetrator, then Muslims might experience strong religious identification because they were threatened by a perpetrator with a different (Christian) religious affiliation. However, if a terrorist attack is conducted by a Muslim perpetrator, then Muslims' religious identification might be less pronounced because the religious affiliation of the perpetrator matches with their own religious affiliation. In contrast, because religious identification is less important for Christians than it is for Muslims, Christians' religious identification might be less affected by the denomination or religious affiliation of a terrorist. As a consequence, Muslims (because of the stronger religious identification) might regard terrorism as less justified if the perpetrators were Christians compared to if they were Muslims, whereas Christians' perceptions of a terrorist attack (because of the less pronounced religious identification) might be less affected by the religion of the perpetrator. Study 3 was designed to test this line of thought.

\section{Study 3}

Muslims and Christians from the CIS read a description of a religiously motivated terrorist attack, which was either conducted by Muslim or Christian aggressors (i.e. threat to religious identity). Subsequently, participants indicated to what extent they were (a) religious, (b) identified with their religion, (c) aggressive, and (d) to what extent they perceived the terrorist attack as justified. Because of the higher importance of religious identity, Muslims were 
expected to regard terrorism as less justified if the perpetrators were Christians than if they were Muslims. In contrast, Christians were not expected to be sensitive to the religious source of the attack. Furthermore, we expected this interaction effect to be mediated by importance of religious identity-and not by a greater aggression potential of Muslims compared to Christians-as was suggested by the results from Study 1 on Westerner's implicit theories about Muslims.

\section{Method}

Participants and design Sixty (25 females and 35 males, ages ranging from 18 to 67 years; $M=39.03, S D=12.22)$ Christians $(N=30$; age: $M=38.93, S D=11.97)$ and Muslims $(N=30$; age: $M=39.13, S D=12.67)$ from the CIS participated in Study 3. The study was based on a 2 (religion of participants: Christian vs. Muslim) $\times 2$ (religion of terrorists: Muslim vs. Christian) factorial between-subject design.

Material and procedure First of all, participants received a description of a terrorist attack, which was conducted either by Muslim or Christian extremists. This description was formulated as a fictive newspaper article and contained the following information to be imagined by the participants:

Religiously motivated aggression and terrorism has increased over the last few years, and has become one of the most challenging social problems facing the modern world. In the following study, we want to investigate the effects of religiously motivated aggression on individuals' cognitions and emotions. In order to prevent biasing your assessments, we have not named the location or date of the following description of a disastrous terrorist attack; needless to say, it was a tragic example of Muslim (Christian) aggression that was conducted in a major city in the CIS some months ago by Muslim (Christian) terrorists. Fourteen people lost their lives and many others were seriously injured. People in that city are still shocked and are desperately trying to reclaim a sense of normality in their lives. A letter from the terrorists revealed that Muslim (Christian) extremists, who approved of using force to further their religious agenda, were responsible for that terrorist attack.
Next, participants filled out the same scales and items as in the previous two studies: intrinsic religiosity $(\alpha=.66)$, importance of religious identity, aggression potential $(\alpha=.86)$, and attitude to the terrorist attack. Finally, participants indicated their religious denomination, were debriefed, informed about the aim of the investigation, and dismissed. Please note that all participants were informed that the described terrorist attack was only fictitious and not real. It was also ensured that no participant left the study with negative emotions or mindsets.

\section{Results and discussion}

A $2 \times 2 \times 4$ MANOVA revealed a significant main effect for the factor 'religion of participants' (multivariate $F(4,53)=4.53, p<.01, \eta^{2}=.26$ ). All means and standard deviations are reported in Table 2. Univariate follow-up analyses revealed that religious identity was more important to Muslims $(M=8.10, S D=3.12)$ than Christians $(M=5.57, S D=3.05),(F(1,56)=15.08$, $\left.p<.01, \eta^{2}=.21\right)$. No further significant differences were revealed by the univariate analyses (all $F_{\mathrm{s}}<1.60$, all $p \mathrm{~s}>.21$ ).

Table 2. Means and standard deviations of dependent variables as a function of participants' own religion and the religion of perpetrators in Study 3

\begin{tabular}{|c|c|c|c|c|}
\hline & \multicolumn{2}{|c|}{$\begin{array}{c}\text { Muslim } \\
\text { participants }\end{array}$} & \multicolumn{2}{|c|}{$\begin{array}{c}\text { Christian } \\
\text { participants }\end{array}$} \\
\hline & $\begin{array}{l}\text { Muslim } \\
\text { terrorists }\end{array}$ & $\begin{array}{l}\text { Christian } \\
\text { terrorists }\end{array}$ & $\begin{array}{l}\text { Muslim } \\
\text { terrorists }\end{array}$ & $\begin{array}{l}\text { Christian } \\
\text { terrorists }\end{array}$ \\
\hline $\begin{array}{l}\text { Intrinsic } \\
\quad \text { religiosity }^{\mathrm{b}}\end{array}$ & $\begin{array}{c}4.92 \\
(2.14)^{a}\end{array}$ & $\begin{array}{c}5.18 \\
(1.04)\end{array}$ & $\begin{array}{c}4.49 \\
(1.68)\end{array}$ & $\begin{array}{c}4.51 \\
(1.56)\end{array}$ \\
\hline $\begin{array}{l}\text { Religious } \\
\text { identity }^{c}\end{array}$ & $\begin{array}{c}6.88 \\
(3.71)\end{array}$ & $\begin{array}{c}9.69 \\
(0.63)\end{array}$ & $\begin{array}{c}5.67 \\
(3.35)\end{array}$ & $\begin{array}{c}4.93 \\
(2.81)\end{array}$ \\
\hline $\begin{array}{l}\text { Aggression } \\
\text { potential }^{\mathrm{d}}\end{array}$ & $\begin{array}{c}2.71 \\
(0.43)\end{array}$ & $\begin{array}{c}2.82 \\
(0.39)\end{array}$ & $\begin{array}{c}2.44 \\
(0.83)\end{array}$ & $\begin{array}{c}2.73 \\
(0.66)\end{array}$ \\
\hline $\begin{array}{l}\text { Attitude } \\
\text { toward } \\
\text { terrorism }^{\mathrm{e}}\end{array}$ & $\begin{array}{c}3.29 \\
\quad(3.80)\end{array}$ & $\begin{array}{c}0.85 \\
(1.52)\end{array}$ & $\begin{array}{c}1.27 \\
(2.19)\end{array}$ & $\begin{array}{c}1.93 \\
(3.24)\end{array}$ \\
\hline
\end{tabular}

Notes: ${ }^{a}$ Standard deviations are indicated in parentheses. ${ }^{\mathrm{b}}$ Scale ranges between 1 and $9 .{ }^{\mathrm{c}}$ Scale ranges between 0 and $10 .{ }^{\mathrm{d}}$ Scale ranges between 1 and 5 . ' Scale ranges between 0 and 10 . 
Furthermore, the multivariate analysis revealed a significant interaction between 'religion of participants' and 'religion of terrorists' (multivariate $\left.F(4,53)=2.62, p<.05, \eta^{2}=.17\right)$. First of all, univariate follow-up analyses for the dependent variable 'attitude towards terrorist attack' revealed a significant two-way interaction between 'religion of participants' and 'religion of terrorists' $\left(F(1,56)=4.27, p=.04, \eta^{2}=.07\right)$. Muslims perceived terrorism to be less justified if it was executed by Christian aggressors than if it was executed by Muslim aggressors $(F(1,28)$ $\left.=4.77, p=.04, \eta^{2}=.15\right)$. In contrast, Christians' attitudes toward terrorism did not differ as a function of whether the terrorist attack was executed by Christian or Muslim terrorists $\left(F(1,28)=0.44, p=.51, \eta^{2}=.02\right)$.

A second univariate follow-up analysis with the dependent variable 'importance of religious identity' revealed a significant two-way interaction between 'religion of participants' and 'religion of terrorists' $\left(F(1,56)=5.30, p=.03, \eta^{2}=.09\right)$. Muslims reported religious identity to be more important if the terrorist attack was conducted by Christian terrorists than if conducted by Muslim terrorists $(F(1,28)=7.25, p=.01$, $\left.\eta^{2}=.21\right)$. By contrast, no differences of importance of religious identity were recorded for Christian respondents when the terrorist attack was conducted by Christian or Muslim terrorists, respectively $\left(F(1,28)=0.42, p=.52, \eta^{2}=.02\right)$.

Mediational analyses Preliminary analyses revealed that only 'importance of religious identity' could be a potential mediator of the interaction effect of 'religion of terrorists' and 'religion of participant' on 'justification of terrorism'. The aggression potential and degree of intrinsic religiosity were not potential mediators. Because the simple effects analysis revealed that only Muslims' attitudes toward terrorism were affected by information about the religious denomination of the terrorists, the following analyses for religious identity as a potential mediator were conducted only for Muslims.

A regression analysis with the predictor 'religion of terrorists' and the criteria 'justification of terrorist attack' revealed a significant regression coefficient $(\beta=.38 ; t(28)=2.18$, $p=.04)$. In a second step, the predictor 'religion of terrorists' significantly affected the expected mediator 'importance of religious identity' $(\beta=-.45 ; t(28)=-2.69, p=.01)$. Third, 'importance of religious identity' as a predictor and 'justification of terrorist attack' as criterion also revealed a significant regression weight $(\beta=-.65 ; t(27)=-4.50, p<.001)$. Finally, a regression analysis with the predictors 'religion of terrorists' and 'importance of religious identity' that simultaneously predicted the criteria 'justification of terrorist attack' revealed a significant regression equation $\left(R^{2}=.43, F(2,27)\right.$ $=10.15, p=.005)$. Although 'importance of religious identity' received a significant regression weight $(\beta=-.60 ; t(27)=-3.66, p<.01)$, 'religion of terrorists' did not reach significance $(\beta=.11$; $t(27)=0.68, p=.51)$. A Sobel Test revealed that the indirect effect of the independent variable (religion of terrorists) on the dependent variable (justification of terrorist attack) via the mediator (importance of religious identity) was significantly different from zero $(Z=2.17$, $p<.03)$. Thus, importance of religious identity mediated the effect of religion of terrorists on the justification of terrorism.

\section{General discussion}

We found that Germans in Munich, Bavaria, expected Muslims to be more intrinsically religious, more aggressive, more strongly identified with their religion, and more supportive of terrorism than Christians, and that assumed/expected positive attitudes toward terrorism were mediated by an expected higher aggression potential of Muslims (Study 1). However, direct surveys of Muslims and Christians in the CIS showed that these religious groups only differed with regard to the importance of their religious identity: Muslims reported a stronger identification with their religion than did Christians (Study 2). From this result, we concluded that Muslims' (relative to Christians') religious identity is more strongly affected by the religion of a terrorist perpetrator, which could possibly result in different attitudes toward terrorism (Study 3). As expected, Muslims assessed a terrorist attack to be less justified if 
it was conducted by Christian extremists than if it was conducted by Muslim extremists. In contrast, Christians' acceptance of a terrorist attack did not depend on whether the perpetrators were Christian or Muslim. Furthermore, this difference between Muslims and Christians was mediated by differences related to importance of religious identity: when importance of religious identity and the religion of perpetrators (Muslim or Christian) were considered together, only the importance of religious identity affected Muslims' attitudes toward terrorism. Note that this result clearly contradicted the Germans' implicit theory that Muslims favor terrorism because they are extraordinarily aggressive. Muslims' attitudes towards terrorism did not depend on an increased aggression potential, but on their own religious identity. Please also note that increased religious identification of Muslims did not lead to more justification of Muslim aggression, but to lowered justification of Christian aggression. This clearly contradicts implicit theories Westerners hold about Muslims (see Study 1).

\section{Limitations}

There were some limitations to our research that must be borne in mind. First of all, our samples were relatively small and thus not likely to be representative of Christians and Muslims elsewhere, nor of perceptions held by Christians and nonreligious individuals elsewhere. Future research should employ larger samples in order to improve our ability to generalize our present findings. Second, although recent research revealed that Muslim youth in the USA are significantly more religious than comparable nonMuslim youth in the USA (Ahmed, 2004), there is doubt as to whether increased importance of religious identity is unique to Islam: other research has also shown that the centrality of religious beliefs in one's life is a component of intrinsic religiosity and religious fundamentalism, and neither of these two constructs are particularly associated with a specific religious content or different religious denomination. For example, Hunsberger, Owusu, and Duck (1999) have shown that the construct of religious fundamentalism operates similarly across religious and cultural contexts. Specifically, for both Ghanaian Muslims and Christians as well as for Canadian Christians, religious fundamentalism was positively correlated with right-wing authoritarianism and positively associated with negative attitudes toward homosexuals (see also Hunsberger, 1996). In addition, Burris and Jackson (2000) have demonstrated that, for a sample of Christians, intrinsic religious orientation was strongly correlated with religious group identification. Intrinsically religious participants, whose religious self-perceptions concerning religious group membership were threatened, showed increased religious self-stereotyping. For these reasons, it is important to acknowledge that the results of the present studies-that illustrate stronger religious identification among Muslim than among Christian participants-may be in part due to the context and/or small samples from which the participants were recruited. Hence, future research should further investigate whether different religious affiliations are associated with differences in religious identification by employing larger samples and different cultures.

Third, Study 1 revealed that German participants perceived Muslims more negatively than they did Christians. This might still be due to evaluative ingroup/outgroup distinctions, because Muslims are considered an outgroup by both German unaffiliated persons and German Christians. Given that unfavorable attitudes toward religious outgroups are quite prevalent (Jackson \& Hunsberger, 1999), it seems possible that social identity processes may still have been relevant to both groups. Fourth and finally, with regard to the findings of Study 3, that Muslims viewed a terrorist attack as less justified if the perpetrators were Christian rather than Muslim, we want to note the potential relevance of historical and current inequalities between some countries that are predominantly Christian versus Muslim in shaping Muslims' perceptions of the justifiability of terrorist attacks. Hence, it would be a fruitful endeavor for future research to control potential (perceived) historical differences between Muslim and Christian countries, and their effect on perceived justifiability of aggressive acts. 


\section{Theoretical and practical implications}

Because implicit theories are used to interpret and evaluate the social world (e.g. Hong et al., 2001), guide social judgments, and inform social actions (e.g. Levy, 1999; Levy et al., 2001), these results might have important implications for understanding and social interaction between the Islamic and Western Christian world: the Western Christian world assumes Muslims to be more aggressive than Christians, and therefore to be more supportive of terrorism than Christians. As a consequence, Muslims might be regarded as potential aggressors threatening the Western world, which would lead to oppressive actions and preventive decisions such as military interventions (e.g. the war in Iraq, 2003, or the war in Afghanistan, 2001), economic embargoes (e.g. Iraq, 1991 to 2003) or interdictions of Islamic symbols (e.g. the interdiction of head scarves of Muslim women in German schools). Consequently, Muslims interpret such actions by the Western Christian sphere to be a threat to their religious identity, which results in a different attitude toward terrorism. This, in turn, confirms implicit opinions and stereotypes that Western people hold regarding Muslims, and results in further encroachments and restrictive actions against Muslims and Islamic countries. This line of thought illustrates how (unjustified) implicit theories about Muslims could lead to a selffulfilling prophecy (e.g. Madon, Jussim \& Eccles, 1997; Rosenthal \& Jacobson, 1968), maintaining or even intensifying a vicious circle. In order to break through this circle, the Western world should avoid threatening Muslims' religious identity. For instance, it should be communicated that military interventions to find terrorists (e.g. the Afghanistan war) are not meant to impair Muslims' religious or cultural identity. To conclude, the present results suggest that it is important for Western Christian society to critically question its own stereotypic beliefs about Muslims in order to promote a better understanding and harmony between cultures.

\section{Note}

1. Please note also that $15-20$ years ago, Christians in Ireland were using terrorism on a frequent basis as a political instrument. We investigated only perceptions and stereotypes of religious groups, and do not propose that attitudes toward terrorism are indeed specific to a certain religion or religious orientation.

\section{References}

Ahmed, S. (2004). Religiosity, identity, and pro-social values and behavior: A study of muslim youth. Fairleigh Dickinson University, US: Univ Microfilms International.

Allport, G. W., \& Ross, J. M. (1967). Personal religious orientation and prejudice. Journal of Personality and Social Psychology, 5, 432-443.

Baron, R., \& Kenny, D. (1986). The moderatormediator variable distinction in social psychological research: Conceptual, strategic, and statistical considerations. Journal of Personality and Social Psychology, 51, 1173-1182.

Bergin, A. E. (1991). Values and religious issues in psychotherapy and mental health. American Psychologist, 46, 394-403.

Burris, C. T., \& Jackson L. M. (2000). Social identity and the true believer: Responses to threatened self-stereotypes among the intrinsically religious British Journal of Social Psychology, 39, 257-278.

Buss, A. H., \& Perry, M. (1992). The aggression questionnaire. Journal of Personality and Social Psychology, 63, 452-459.

Dweck, C. S., Chiu, C., \& Hong, Y. (1995). Implicit theories and their role in judgments and reactions: A world from two perspectives. Psychological Inquiry, 6, 267-285.

Feagin, J. R. (1964). Prejudice and religious types: A focused study of Southern fundamentalists. Journal for the Scientific Study of Religion, 4, 3-13.

Hill, P. C., \& Pargament, K. I. (2003). Advances in the conceptualization and measurement of religion and spirituality: Implications for physical and mental health research. American Psychologist, 58, 64-74.

Hong, Y., Levy, S. R., \& Chiu, C. (2001). The contribution of the lay theories approach to the study of groups. Personality and Social Psychology Review, 5, 98-106.

Hunsberger, B. (1996). Religious fundamentalism, right-wing authoritarianism, and hostility toward homosexuals in non-Christian religious groups. International Journal for the Psychology of Religion, 6, 39-49.

Hunsberger, B., Owusu, V., \& Duck, R. (1999). Religion and prejudice in Ghana and Canada: Religious fundamentalism, right-wing 
auttoritarianism and attitudes toward homosexuals and women. International Journal for the Psychology of Religion, 9, 181-194.

Jackson, L. M., \& Hunsberger, B. (1999). An intergroup perspective on religion and prejudice. Journal for the Scientific Study of Religion, 38, 509-523.

Levy, S. R. (1999). Reducing prejudice: Lessons from social-cognitive factors underlying perceiver differences in prejudice. Journal of Social Issues, 55, 745-765.

Levy, S. R., Plaks, J. E., Hong, Y. Y., Chiu, C. Y., \& Dweck, C. S. (2001). Static vs. dynamic theories and the perception of groups: Different routes to different destinations. Personality and Social Psychology Review, 5, 156-168.

Madon, S., Jussim, L., \& Eccles, J. (1997). In search of the powerful self-fulfilling prophecy. Journal of Personality and Social Psychology, 72, 791-809.

Regnerus, M. D. (2003). Linked lives, faith, and behavior: An intergenerational model of religious influence on adolescent delinquency. Journal for the Scientific Study of Religion, 42, 189-203.

Rosenthal, R., \& Jacobson, L. (1968). Pygmalion in the classroom: Teacher expectation and pupils' intellectual development. New York: Holt, Rinehart \& Winston.

Tajfel, H. (1982). Social psychology and intergroup relations. Annual Review of Psychology, 33, 1-39.

Zwingmann, C., Hellmeister, G., \& Ochsmann, R. (1994). Intrinsische und extrinsische
Orientierung: Fragebogenskalen zum Einsatz in der empirisch-religionspsychologischen Forschung [Intrinsic and extrinsic religious orientation: Questionnaire scales in use for psychological studies of religion]. Zeitschrift für Differentielle und Diagnostische Psychologie, 15, 131-139.

Paper received 9 September 2004; revised version accepted 7 February 2006.

\section{Biographical Notes}

PETER FISCHER finished his PhD in 2003 at LudwigMaximilians-University, Munich, and habilitated there in July 2007. His main research interests are in information processing after decisions, pro- and antisocial behavior as well as psychology of terrorism.

TOBIAS GREITEMEYER finished his PhD in 2001 at Ludwig-Maximilians-University, Munich, and habilitated there in 2004. His main research interests are group decision-making, biased assimilation, prosocial behavior, and attribution.

ANDREAS Kastenmüller finished his $\mathrm{PhD}$ in 2006 at Ludwig-Maximilians-University, Munich. His main research interests are information processing after decisions, terrorism, and prosocial behavior. 